\section{STATISTICS TEACHING PRACTICE AT CZECH UNIVERSITIES WITH EMPHASIS ON STATISTICAL SOFTWARE}

\begin{abstract}
This paper aims to reveal the beliefs of students and fresh university graduates about teaching statistics during their university studies with focus on using statistical software. The objective is to detect the approach of faculties to statistics education and to find out which didactic materials and teaching methods are mainly used. Students' opinions are captured by means of a questionnaire survey and analysed both quantitatively and qualitatively. The results show the increasing importance of quantitative research and the necessity of improving statistical thinking. Unfortunately, the teaching methods used in various statistical courses are outdated and unattractive for most students. They call for an active and modern approach. Teaching statistics with the statistical software support seems to be the right way to make statistics accessible to students. The recommendation is to take students' notions into account when preparing statistical courses.
\end{abstract}

\section{KEYWORDS}

\section{Statistical courses, statistical software, student's demands, teaching statistics, university student, questionnaire survey}

\section{HOW TO CITE}

Mazouchová A., Jedličková T., Hlaváčová L. (2021) 'Statistics Teaching Practice at Czech Universities with Emphasis on Statistical Software', Journal on Efficiency and Responsibility in Education and Science, vol. 14, no. 4, pp. 258-269. http://dx.doi.org/10.7160/ eriesj.2021.140405

\section{Aneta Mazouchová ${ }^{1 凶}$ \\ Tereza Jedličková2 \\ Lucie Hlaváčová ${ }^{3}$}

${ }^{1}$ Department of Economic Statistics,

Prague University of Economics and

Business, Czech Republic

${ }^{2}$ Institute of Geology and

Paleontology, Faculty of Science,

Charles University, Czech Republic

${ }^{3}$ Department of Biology and

Environmental Studies, Faculty of

Education Charles University, Czech

Republic

anetamazouchova@gmail.com

\section{Article history}

Received

December 12, 2020

Received in revised form

June 11, 2021

Accepted

November 10, 2021

Available on-line

December 20, 2021

\title{
Highlights
}

- The research of this paper was conducted both quantitatively and qualitatively.

- The survey was carried out across all Czech universities and 763 respondents took part.

- Students consider the teaching methods of statistics at Czech universities to be outdated and too theoretical.

- According to the addressed students, Czech universities do not provide students with the opportunity to get acquainted with any statistical software.

- To be effective, the teaching methods of statistics have to adapt to students' needs, especially in the field of humanities.

\section{INTRODUCTION}

University students frequently consider statistics as one of the most challenging subjects. They often even speak about the fear of statistics (Cobb, 1992; Ralston et al., 2016). The fear/anxiety of statistics is described both in foreign (e.g. Steinberger, 2020) and Czech studies (e.g. Hybšová, 2017; Widenská, 2014). Many studies examine students' attitudes toward statistics and address the issue of teaching statistics to eliminate the fear of statistics (e.g. Dempster and McCorry, 2009; Kurniawan et al., 2019; Ralston et al., 2016). However, such studies are unique in the Czech Republic and have the character of ,,best practice“ rather than research (e.g. Hindls and Hronová, 2005; Skalská, 2019).

Teachers of statistics and other statistical subjects face such prejudice. In response, sufficient attention must be paid not only to the course design and the learning context, but also to the mind of individual students and motivating their learning process (Law, Lee and Yu, 2010). The subject must adapt didactically to a specific field of study to view statistics as a science that accompanies and helps students find answers for scientific questions (Hybšová, 2017). The development and increase of teaching quality help to greater popularity and understanding statistics as a scientific discipline.

Given the above mentioned, preparation of a quality statistical subject is demanding and affected by numerous factors, e.g. the field of study, the initial level of mathematical and statistical knowledge that differ among students. Scheduling of statistical subjects during studies plays an important role, as well. Students in higher study groups are more likely to be motivated in statistics courses because they can assume the need to use 
statistics when working on their thesis. According to Velleman and Moore (1996) it is essential to motivate students of introductory courses and to change their negative approach towards statistics mainly influenced by negative perceptions of statistics by population.

Selection and utilisation also affect the resulting quality (Hybšová, 2017). Despite numerous studies about innovations in the education of statistics (see, e.g. Huynh and Baglin, 2017; Billig and Waterman, 2014), its teaching in the Czech Republic remains very rigid. It is not uncommon that teachers prefer the "pen-and-paper" method and other didactic tools like statistical software (SW) remain unused. An example of the efficiency and usefulness of using interactive materials during the education process was verified and published by Aberson et al. (2002) and Law, Lee and Yu (2010) confirmed the efficiency and usefulness of electronic education in their paper. Using statistical software has motivational potential as its use eliminates the stress caused by statistical calculations and students focus more on the practical use of statistics (Hsu, Wang and Chiu; 2009). Stejskalová et al. (2019) describe the case studies of real-life students to consider an appropriate complement to the traditional method of teaching.

Students are afraid of calculations (Cobb, 1992). Therefore, using statistical software in teaching statistics offers a way to perform the feared statistical calculations. Thus, students focus more on practical significance (Hsu, Wang and Chiu; 2009). There are a number of paid as well as free statistical programmes that can be used during a course. The teacher needs to consider the choice of software to work with carefully. This selection determines statistical software that the students are the most likely to use when writing their thesis. If the teacher wants the students to use statistics after graduation, the choice should tend to software that does not require an expensive licence. Another reason for choosing a specific software is e.g. the existence of demonstrative tutorials. According to Poláčková and Jindrová (2010) multimedia presentations can make the teaching process of statistical classes more efficient. Therefore, students can understand how to work with and use statistical software faster and easier. These tutorials are also beneficial for teachers, who can spend more time explaining the statistical methods instead of focusing on the software. Tutorials can help less experienced information technology (IT) users to overcome potential problems with navigation through the statistical software.

The objective of this paper is to detect the approach of faculties to teaching statistics, to find out which didactic materials and teaching methods are mainly used and to highlight the main issues and concerns of students regarding statistics. The paper is divided into method description, results and discussion. The conclusion summarises the most important results and recommendations for further research.

This paper follows up on the conference paper of Mazouchová, Jedličková and Hlaváčová (2020).

\section{METHODOLOGY AND RESEARCH QUESTIONS}

This paper focuses on the use of statistical software in university studies. The respondents were students in at least their second year of study and fresh graduates from all Czech public universities. A self-administered survey was employed. In line with De Leeuw and Hox (2008), respondents received an email that invited them to respond to a web-based survey, using a clickable link for easy access included in a personalised email. Respondents were addressed through all public Facebook groups for students and graduates. The questionnaire included a sorting question about the year of study of the respondent. The respondents could continue answering the questionnaire if they were studying at least the second year of a bachelor programme or finished university less than 5 years ago.

We tried to obtain the largest possible sample to capture the overall situation in the Czech Republic. Within this sampling, it is predictable that the experience varies among different fields of study. This must be taken into account when interpreting the results.

The survey received a total of 763 fully completed questionnaires from students of 14 public universities. Women represented $79 \%$ of the respondents, men $21 \%$. This trend is in line e.g. with Curtin, Presser and Singer (2000), Moore and Tarnai (2002) or Singer, van Hoewyk and Maher (2000). $39 \%$ of the questionnaires were responded by university graduates, $18 \%$ of respondents were students of a bachelor study programme, $36 \%$ studied in a master programme and $7 \%$ of the respondents studied in doctoral studies.

The first part of the questionnaire focused on finding out whether the respondents attended any statistics course during their university studies. The next part concentrated specifically on the use of statistical software in their classes and the student's ability to use the given software. Subsequently, the respondents were asked about the use of statistical methods when processing their final theses. Finally, respondents evaluated several statements related to statistics and its use during their university studies on the 5-point Likert scale.

We used the Hierarchical Cluster Analysis with Ward's Method to verify the structure of the responses to the sentiment questions. The arising clusters divided respondents into 4 groups (see Table 2). The clusters were frequent and demonstrated rather even distribution.

The dependence of the statements on sex and on student participation in at least one statistics course was investigated. For the purpose of comparison, the statements were recorded as follows: 1 = I totally disagree, $2=\mathrm{I}$ do not agree, $3=\mathrm{I}$ do not know, 4 = I agree, 5 = I completely agree. Means and standard deviation of groups were calculated. Mann-Whitney U tests were applied to compare two groups. P-value was evaluated at the $5 \%$ level of significance.

The final question of the survey asked respondents to freely comment on the given issue. 117 participants $(15 \%)$ used this opportunity. Their open responses were qualitatively evaluated by means of content analysis. The initial analysis used the Open Coding in Hand method according to Hendl (2005) and Strauss and Corbin (1999). The response texts were searched for meaningful units, which were then marked. In accordance with Erlingsson and Brysiewicz, 2017) the meaningful units consisted of single words, word sequences or whole sentences. Such marked units received codes and were entered into tables, creating a clear list according to Lee and Fielding (2004). 
Subsequently, the codes were adjusted, statements with the same content and different formulation were joined and marked with a modified code (Švaříček and Šed'ová, 2007). Some codes were left on purpose in the long and detailed version to avoid losing data by shortening them. The listed codes were then analysed according to Švaříček and Šed'ová (2007), the same topics found and codes grouped into categories and subcategories. Relations and key topics were identified.

Due to the fact that the respondents studied a wide range of study fields, this paper rather represents a survey. It is not advisable to generalise the conclusions using inductive statistical methods. The acquired data were evaluated only by means of descriptive statistics.

Five research questions were specified with respect to the defined objectives:

- What statistical software do university students know and are able to use?

- What problems do students face when using statistical software?

- Do university students process the statistical data for their thesis themselves?

- What factors affect opinions regarding statistics?

- What comments do students have in terms of statistical courses at Czech universities?

\section{RESULTS}

Initially, we asked respondents if they completed any statistics course during their studies. $31 \%$ of respondents did not complete any statistics subject while $34 \%$ of respondents completed one semester of statistics and $35 \%$ completed two and more semesters.

The following part of the questions was intended only for students who completed at least one statistics course $(n=526)$. The questions concentrated on the statistical software used in the classes. Respondents could choose from suggested answers with various types of statistical software (including MS Excel) or write their own response.

More than a half of the respondents (53\%) used MS Excel, while $28 \%$ stated they used no statistical software at all. Some students also used Statistica (19\%), SPSS (13\%) and R (10\%) in their classes. Jamovi (3\%), SAS (2\%), JASP (2\%), Gretl $(1 \%)$ and GraphPad $(0,5 \%)$ remain virtually unused. Figure 1 shows software mentioned more than once in the responses.

The third part of the questionnaire concentrated on the use of statistical methods when processing a thesis. $72 \%$ of respondents stated that they used statistical methods to process their theses. $20 \%$ out of them admitted that the data for their theses were processed by a statistician, their supervisor or another person.

The main question of the survey asked what statistical programme respondents know and can use. The one known and used by almost all respondents was MS Excel, which, in their opinion, they can use well or at least partially. Other known programmes include Statistica, SPSS, R and SAS. Paradoxically, the JASP and Jamovi freeware software are the least known and used (see Figure 2).

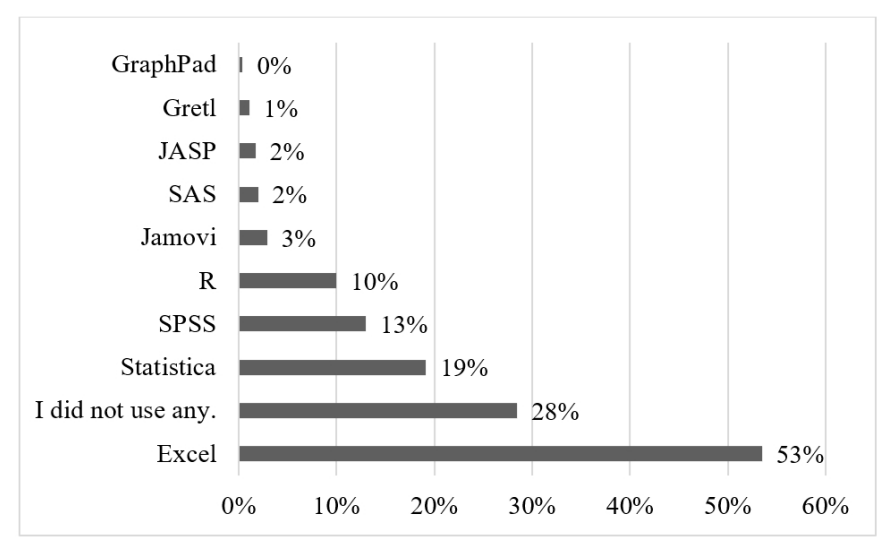

Figure 1: Statistical software used in lessons $(n=526), 2019-2020$

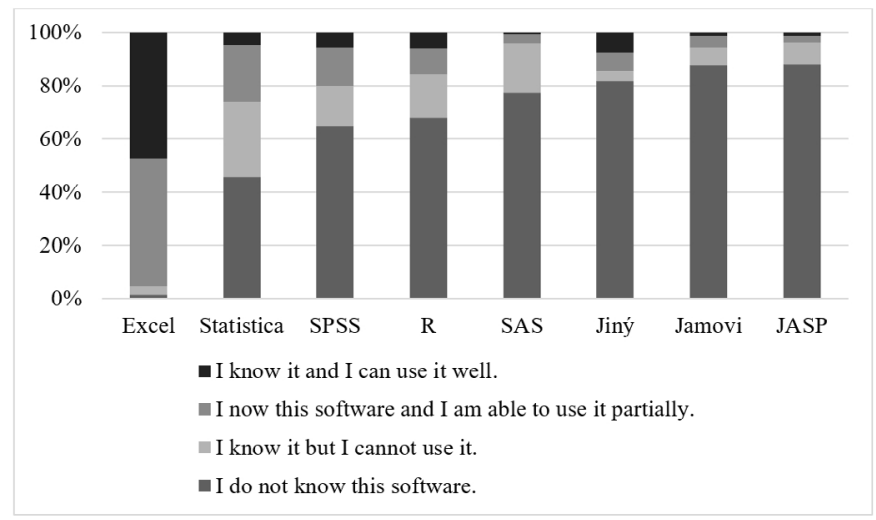

Figure 2 Answers to question “What software do you know and can use?” ( $n=763)$, 2019-2020 
The next part of the questionnaire asked the respondents to evaluate eight statements. They had a five-point scale available to express their sentiment. Table 1 shows the statements and answers. $55 \%$ of respondents claim that statistical software in English represents no problem. Comprehending statistics constitutes a more complicated issue for many students, with $55 \%$ of respondents stating that they do not understand statistics. Moreover, respondents have no preference between qualitative and quantitative research $(38 \%$ prefer quantitative and $36 \%$ qualitative research). Almost a third of respondents $(32 \%)$ state that their supervisor advised them on the appropriate methods for data processing.

\begin{tabular}{|c|c|c|c|c|c|}
\hline Statement & $\begin{array}{l}\text { I totally } \\
\text { disagree } \\
\text { (1) }\end{array}$ & \begin{tabular}{|} 
I do not \\
agree \\
$(2)$
\end{tabular} & $\begin{array}{l}\text { I do not } \\
\text { know } \\
\text { (3) }\end{array}$ & $\begin{array}{l}\text { I agree } \\
\text { (4) }\end{array}$ & \begin{tabular}{|c} 
I completely \\
agree \\
(5)
\end{tabular} \\
\hline Statistical software in English is a problem. & $25 \%$ & $30 \%$ & $15 \%$ & $22 \%$ & $7 \%$ \\
\hline The problem is that I do not understand statistics. & $10 \%$ & $22 \%$ & $13 \%$ & $36 \%$ & $19 \%$ \\
\hline $\begin{array}{l}\text { The problem is that I do not understand statistics and the software is in } \\
\text { English. }\end{array}$ & $17 \%$ & $28 \%$ & $18 \%$ & $21 \%$ & $15 \%$ \\
\hline $\begin{array}{l}\text { I have a block towards statistics. I do not understand it and I do not want } \\
\text { to understand it. }\end{array}$ & $23 \%$ & $37 \%$ & $16 \%$ & $15 \%$ & $8 \%$ \\
\hline I prefer qualitative research to a quantitative one. & $13 \%$ & $25 \%$ & $27 \%$ & $23 \%$ & $13 \%$ \\
\hline My supervisor does not understand statistics. & $27 \%$ & $22 \%$ & $37 \%$ & $8 \%$ & $4 \%$ \\
\hline My supervisor required the use of the statistical method in the thesis. & $23 \%$ & $23 \%$ & $16 \%$ & $21 \%$ & $17 \%$ \\
\hline My supervisor suggested me the appropriate method of data processing. & $24 \%$ & $27 \%$ & $18 \%$ & $23 \%$ & $9 \%$ \\
\hline
\end{tabular}

Table 1: Relative frequencies of statements $(n=763)$

\section{Cluster analysis of statements}

Cluster analysis divided respondents into four clusters according to their answers to sentiment questions. Centroids were calculated for individual clusters (see Table 2).

Cluster $1(n=171)$ includes respondents who assessed a lot of the statements in a neutral manner being unable to judge them. However, they feel no block in terms of statistics. Their supervisor requires statistics as a part of thesis and the respondents assume that their supervisor understands statistics. Cluster $2(n=163)$ groups respondents stating that they do not understand statistics and prefer qualitative research. Statistical software in English represents a problem for them. However, their thesis supervisor did not require statistics when working on the thesis or suggest any statistical methods.
Cluster $3(n=132)$ includes respondents who have no problem with statistical software in English. They do not understand statistics as such, do not wish to understand it and feel that they have a mental block in terms of statistics. They prefer qualitative research, although their thesis supervisor requested the use of statistics in the thesis and suggested specific statistical methods.

Cluster $4(n=228)$ groups respondents who stated negative sentiment towards all statements. They have no problem with statistical software in English. They understand statistics and prefer quantitative research. They assume that their thesis supervisor understands statistics, although no use of statistical data processing was required in the thesis. These respondents found their respective data processing methods themselves.

\begin{tabular}{|c|c|c|c|c|}
\hline Statement / Cluster & 1 & 2 & 3 & 4 \\
\hline It is a problem if statistical software is in English. & 3 & 3 & 2 & 2 \\
\hline It is a problem that I do not understand statistics. & 3 & 4 & 4 & 2 \\
\hline $\begin{array}{l}\text { The combination of the fact that the software is in English and that I do not understand statistics } \\
\text { represents a problem. }\end{array}$ & 3 & 4 & 3 & 2 \\
\hline I feel a mental block towards statistics. I do not understand it and I do not wish to. & 2 & 3 & 4 & 2 \\
\hline I prefer qualitative research to quantitative. & 3 & 4 & 4 & 2 \\
\hline My thesis supervisor does not understand statistics. & 2 & 3 & 3 & 2 \\
\hline My thesis supervisor required that my thesis includes the use of statistics. & 4 & 2 & 4 & 2 \\
\hline My thesis supervisor suggested what statistical methods I should use to process the data. & 3 & 2 & 4 & 2 \\
\hline
\end{tabular}

\section{Table 2: Final Cluster Centres}

\section{Relation between statements on selected factors}

Table 3 shows the means and standard deviations for men and women. Compared to men (mean $=2.12)$, more women (mean $=2.66$ ) consider as a problem that statistical software is in English ( $p$-value $<0.001)$. The female group of respondents $($ mean $=3.37)$ also report having problems with statistics more often compared to the male group $($ mean $=3.06, p$-value $=0.007)$.
The combination of English and statistics is also a more significant problem for women $($ mean $=2.97)$ than men $($ mean $=2.48$, $p$-value $<0.001)$. Women evaluate their relationship towards statistics as a block more often (mean $=2.56)$ then men (mean $=2.20, p$-value $=0.002$ ). Other differences of statements are not significant at the $5 \%$ level - groups of male and female respondents evaluate both these statements equally. 


\begin{tabular}{|c|c|c|c|c|c|}
\hline \multirow[b]{2}{*}{ Statements } & \multicolumn{2}{|c|}{ Men } & \multicolumn{2}{|c|}{ Women } & \multirow[b]{2}{*}{$p$-value } \\
\hline & Mean & Std. Deviation & Mean & Std. Deviation & \\
\hline Statistical software in English is a problem. & 2.12 & 1.185 & 2.66 & 1.273 & $<0.001 * * *$ \\
\hline The problem is that I do not understand statistics. & 3.06 & 1.245 & 3.37 & 1.290 & $0.007^{* *}$ \\
\hline $\begin{array}{l}\text { The problem is that I do not understand statistics and } \\
\text { the software is in English. }\end{array}$ & 2.48 & 1.310 & 2.97 & 1.326 & $<0.001 * * *$ \\
\hline $\begin{array}{l}\text { I have a block towards statistics. I do not understand it } \\
\text { and I do not want to understand it. }\end{array}$ & 2.20 & 1.157 & 2.56 & 1.266 & $0.002 * *$ \\
\hline I prefer qualitative research to quantitative one. & 2.88 & 1.221 & 3.00 & 1.232 & 0.302 \\
\hline My supervisor does not understand statistics. & 2.38 & 1.143 & 2.41 & 1.111 & 0.774 \\
\hline $\begin{array}{l}\text { My supervisor required use of statistical method in the } \\
\text { thesis. }\end{array}$ & 2.83 & 1.464 & 2.94 & 1.424 & 0.417 \\
\hline $\begin{array}{l}\text { My supervisor suggested me appropriate method of } \\
\text { data processing. }\end{array}$ & 2.59 & 1.307 & 2.67 & 1.304 & 0.487 \\
\hline
\end{tabular}

Table 3: Mann-Whitney $U$ test comparing statements by gender (Men $n=162$ and Women $n=601$ ) $* * *=$ significant at level 0.001 , $*$ = significant at level $0.01, *=$ significant at level 0.05

Table 4 describes the means and standard deviations of students who completed at least one statistics course and those who did not. Students without any completed course of statistics tend towards qualitative research $($ mean $=3.21)$ in comparison with students who participated and completed at least one statistics course $($ mean $=2.89, p$-value $=0.010)$. Those who completed of at least one statistics course are more confident in the supervisor's knowledge of statistics (mean $=2.34)$ than students with no completed statistics course (mean $=2.58$, $p$-value $=0.014)$. Respondents who participated in some statistics course often pointed out their supervisor's request to use statistical methods in the final thesis (mean $=3.00$ ) compared to the group of respondents without a completed statistics course $($ mean $=2.66, p$-value $=0.029)$.

\begin{tabular}{|c|c|c|c|c|c|}
\hline \multirow{2}{*}{ Statements } & \multicolumn{2}{|c|}{$\begin{array}{c}\text { Completed at least one statistic } \\
\text { course }\end{array}$} & \multicolumn{2}{|c|}{$\begin{array}{l}\text { Not completed any statistic } \\
\text { course }\end{array}$} & \multirow{2}{*}{$p$-value } \\
\hline & Mean & Std. Deviation & Mean & Std. Deviation & \\
\hline Statistical software in English is a problem. & 2.54 & 1.289 & 2.55 & 1.237 & 0.915 \\
\hline The problem is that I do not understand statistics. & 3.30 & 1.319 & 3.34 & 1.180 & 0.534 \\
\hline $\begin{array}{l}\text { The problem is that I do not understand statistics and } \\
\text { the software is in English. }\end{array}$ & 2.86 & 1.376 & 2.89 & 1.231 & 0.590 \\
\hline $\begin{array}{l}\text { I have a block towards statistics. I do not understand it } \\
\text { and I do not want to understand it. }\end{array}$ & 2.47 & 1.283 & 2.53 & 1.153 & 0.496 \\
\hline I prefer qualitative research to a quantitative one. & 2.89 & 1.253 & 3.21 & 1.132 & $0.010 * *$ \\
\hline My supervisor does not understand statistics. & 2.34 & 1.164 & 2.58 & 0.965 & $0.014 * *$ \\
\hline $\begin{array}{l}\text { My supervisor required the use of the statistical method } \\
\text { in the thesis. }\end{array}$ & 3.00 & 1.472 & 2.66 & 1.281 & $0.029 *$ \\
\hline $\begin{array}{l}\text { My supervisor suggested me the appropriate method of } \\
\text { data processing. }\end{array}$ & 2.68 & 1.348 & 2.57 & 1.161 & 0.634 \\
\hline
\end{tabular}

Table 4: Mann-Whitney $U$ test comparing 2 groups - the absolvents of at least one statistics course $(n=526)$ and the respondents without completing any statistics course $(n=237) * * *=$ significant at level $0.001, *=$ significant at level $0.01, *=$ significant at level 0.05

To better understand the effect of teaching statistics with the support of statistical software, students who completed at least one statistics course $(n=526)$ were divided into two groups: respondents who used statistical software in their courses, and respondents who did not use statistical software in their courses. All statements differ between those two groups (see table 5). Students with a completed statistics course supported with statistical software have fewer problems with the English language $(p$-value $=0.005)$, with understanding statistics
( $p$-value $<0.001)$ and also with the combination of English and statistics $(p$-value $<0.001)$. These respondents also feel less antipathy towards statistics $(p$-value $<0.001)$ and prefer quantitative research ( $p$-value 0.006). The students who completed at least one statistics course are also more confident in the supervisor's knowledge of statistics ( $p$-value $=0.026$ ). Their supervisor required more often the use of statistical methods in the thesis ( $p$-value $=0.001$ ) and suggested appropriate methods of data processing $(p$-value $=0.007)$. 


\begin{tabular}{|c|c|c|c|c|c|}
\hline \multirow[b]{2}{*}{ Statements } & \multicolumn{2}{|c|}{ Without statistical software } & \multicolumn{2}{|c|}{ With statistical software } & \multirow[b]{2}{*}{$p$-value } \\
\hline & Mean & Std. Deviation & Mean & Std. Deviation & \\
\hline Statistical software in English is a problem. & 2.86 & 1.303 & 2.46 & 1.273 & $0.005^{* *}$ \\
\hline The problem is that I do not understand statistics. & 3.75 & 1.197 & 3.17 & 1.328 & $0.000 * * *$ \\
\hline $\begin{array}{l}\text { The problem is that I do not understand statistics and } \\
\text { the software is in English. }\end{array}$ & 3.31 & 1.352 & 2.75 & 1.357 & $0.000 * * *$ \\
\hline $\begin{array}{l}\text { I have a block towards statistics. I do not understand it } \\
\text { and I do not want to understand it. }\end{array}$ & 2.88 & 1.275 & 2.37 & 1.268 & $<0.001 * * *$ \\
\hline I prefer qualitative research to quantitative one. & 3.21 & 1.282 & 2.82 & 1.233 & $0.006^{* *}$ \\
\hline My supervisor does not understand statistics. & 2.57 & 1.197 & 2.28 & 1.149 & $0.026^{*}$ \\
\hline $\begin{array}{l}\text { My supervisor required use of statistical method in the } \\
\text { thesis. }\end{array}$ & 2.59 & 1.466 & 3.10 & 1.456 & $0.001 * *$ \\
\hline $\begin{array}{l}\text { My supervisor suggested me appropriate method of } \\
\text { data processing. }\end{array}$ & 2.37 & 1.344 & 2.75 & 1.339 & $0.007 * *$ \\
\hline
\end{tabular}

Table 5: Mann-Whitney $U$ test comparing 2 groups - absolvents of statistical course using statistical software $(n=107)$ and absolvents of statistical course without statistical software $(n=419) * * *=$ significant at level $0.001, *=$ significant at level $0.01, *=$ significant at level 0.05

\section{Students' comments on the statistics courses}

The final part of the questionnaire gave respondents the opportunity to freely comment on the topic of statistics classes at university and the used software. Content analysis divided the responses into seven categories (Table 6 and 7). Most commonly, students commented on the need for statistics classes, the character of the classes in statistics courses, including the methods and teaching forms used, as well as the teacher's personality.

Most respondents see the need for statistics regarding writing the final thesis, arising either from their own needs or the supervisor's demands. The notion occurred several times that to correctly understanding and interpreting expert publications requires at least basic knowledge of statistics. On the other hand, the majority of humanities students stated that they do not need statistics very much and that, in their opinion, it is given too much space in their study.

Students also assessed the general character of statistics classes. A part of students perceives statistics classes in a positive way, considering them of good quality and being satisfied with the course. More students expressed their dissatisfaction, however. Complaints were expressed about the insufficient contents of statistics classes. Courses lacked the basics and principles of statistics and students missed the explanation of the process of using individual statistical methods. Completing their courses did not provide the participants with sufficient knowledge for practice. Others mentioned disproportionate demands towards students. Respondents often considered classes too complicated, detailed and often too strict as many ended their study because of statistics. Some students stated that statistics spoils the whole study. Organisational issues represent another commonly mentioned negative, mainly chaotic organization of courses, i.e. the courses are not continual. Students lack the space to master statistics and practice it. Some students also stated that they did not encounter statistics in their studies at all.
Methods and forms of classes constitute another category of statements. Students believe that statistics should be taught in a more entertaining form and simpler way not to deter students in their first contact with the discipline. Respondents consider the current conception of classes for non-mathematicians, or humanities students to be rather unsuitable. Some stated that they would welcome classes with the use of SW to bring the discipline nearer to students as they completed a course with no use of SW whatsoever, or used to a limited extent. If SW was used in a course, respondents criticised classes teaching them to merely click a button to see the result. This brings no practical benefit in their opinion.

In general, respondents consider the approach to statistics problematic when everything is only seen from the theoretical point of view and explained by putting forward definitions with little sense without specific examples. Respondents demand a practical approach, active practice of illustrative examples of various statistical methods with clear connection to real life. The fourth category concerns the teacher's personality. Respondents mainly evaluated whether the teacher could explain given issues and the attitude to students. Students often demand teachers to be able to both understand and explain statistics. Teachers often settle for students memorizing statistical procedures without context. They rarely require a true understanding of statistics and an ability to interpret results. Respondents often pointed out that a teacher's attitude towards students should be patient. Some students came across a teacher with the attitude that whoever does not understand should not be there. Teachers assume students' perfect knowledge of secondary-school mathematics even when studying psychology and other humanities. Others criticised their supervisor for not understanding statistics too much, although the supervisor or the study system demands statistics in the final thesis. Moreover, few people are willing to help students with statistics. 
The fifth category includes statements concerning the issues in statistics classes. Humanities students consider statistics a complicated discipline as they are used to studying in a different way than statistics requires. Students often admitted to problems with understanding what test or method to use in particular situations and identifying it from results or interpreting results. Respondents also mentioned inconsistent use of Czech statistical terminology. Each teacher uses a different one and students have to deal with it, sometimes even in English.

The survey focused on statistical software, which constitutes another frequently mentioned area and another category. Respondents tend to believe that statistical software is necessary for statistics classes. Besides the fact that using the software can save students a lot of time, knowing how to use particular software proves necessary for applying knowledge in practice. Students mostly learned to know the Statistica, Excel, R, and SPSS software in classes. Respondents praise the quality of the SPSS tutorials available on Youtube, as well as online courses for the $\mathrm{R}$ software. Those who had statistics also complained that they only studied paid software that they could not use after the study.

Trust in the field of statistics comprises the final, relatively narrow category. Some respondents consider statistics a strange field that contradicts human understanding. Moreover, some think that there are as many results as there are experts.

I'd appreciate an obligatory selected course of statistics

Too little statistics, e.g. in comparison with abroad

NEED FOR STATISTICS

The quantitative approach is too much promoted in humanities

Necessary in the final thesis

Reasons for knowledge Final thesis supervisor demands it

of statistics Understanding and interpreting research papers correctly

Suitable tool for practising logical thinking

\begin{tabular}{|c|c|c|}
\hline \multirow{10}{*}{$\begin{array}{l}\text { THE CHARACTER OF STATISTICS } \\
\text { CLASSES }\end{array}$} & \multirow{2}{*}{$\begin{array}{l}\text { Satisfaction with the } \\
\text { course }\end{array}$} & Quality classes \\
\hline & & Satisfied, the course was beneficial \\
\hline & \multirow{3}{*}{$\begin{array}{l}\text { Course unsatisfactory } \\
\text { in contents }\end{array}$} & Missing the explanation of statistics fundamentals \\
\hline & & The process of using individual methods was not clarified \\
\hline & & Low quality of classes \\
\hline & \multirow{3}{*}{$\begin{array}{l}\text { Disproportionate } \\
\text { demands on students }\end{array}$} & Complicated and detailed classes \\
\hline & & Disproportionate time investment into learning statistics \\
\hline & & Strict - many students ended because of it; it's frustrating \\
\hline & \multirow{2}{*}{$\begin{array}{l}\text { Organisation } \\
\text { deficiencies }\end{array}$} & Chaotically arranged classes, not continual \\
\hline & & Did not take a statistics course during study \\
\hline \multirow{8}{*}{$\begin{array}{l}\text { METHODS AND FORMS OF } \\
\text { CLASSES }\end{array}$} & \multirow{4}{*}{$\begin{array}{l}\text { Too much theory, too } \\
\text { little practice }\end{array}$} & Everything solved theoretically \\
\hline & & Dictating definitions, the pen-and-paper method \\
\hline & & The classes should be more practical \\
\hline & & No specific practical examples \\
\hline & \multirow{4}{*}{ Ability to captivate } & Need for a more fun form of classes \\
\hline & & Need for a fool-proof way of teaching \\
\hline & & Classes unsuitable for non-mathematicians \\
\hline & & Need for teaching statistics with statistical software \\
\hline
\end{tabular}

Table 6: Categorized responses from free comments with regard to the given issue - part I 


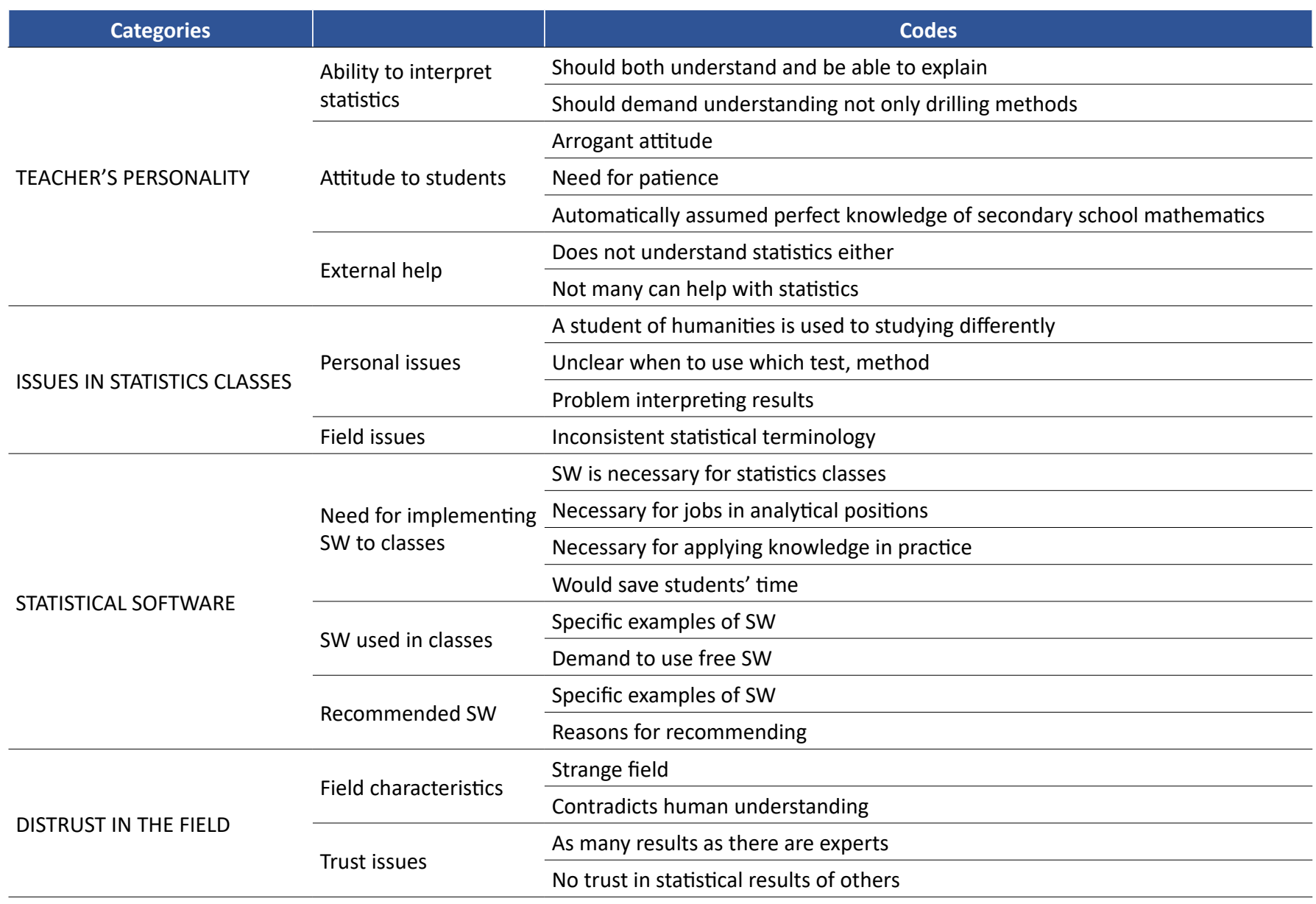

Table 7: Categorized responses from free comments with regard to the given issue - Part II

\section{DISCUSSION}

Statistics and its applications find use in all study fields. According to the results, $38 \%$ of thesis supervisors demand the use of statistics from their students. It can be assumed, though, that if there is only one statistically oriented course during their study, students are not likely to be able to interpret the results for their theses. This corresponds to the fact that $20 \%$ of respondents that used statistics in their thesis did not process the data themselves. They rather leave the processing on a statistician, the supervisor or someone else. Considering that students usually had only one semester of statistics and are not sure about the calculations, it is understandable that they leave data processing to someone else. Moreover, the mentioned $20 \%$ of respondents is a lower estimate as not everyone admits to delegating the data processing.

The survey showed that if students encounter statistics courses in the minimum extent, the conception of the courses proves crucial.

The results show that teaching statistics at universities is still implemented by means of traditional teaching methods, which, according to Mustafa (1996), are ineffective. The main problem is that students fail to establish a clear link between statistics and its uses in the real world and ask themselves: What am I going to use this for? Nonetheless, university studies anticipate the use of statistics, mainly for the thesis. Sufficient knowledge of different possibilities of statistical data processing influences the design of a thesis and gives students new possibilities not only for evaluating data but also for creating research tools and their distribution. Before each statistic course, individual faculties should analyse students' attitudes and the level of their current knowledge of statistics. Only if the needs of specific students are considered, the teaching of statistical courses may be maximally effective. Suggestions from teacher preparation efforts include a stronger focus on teaching and learning statistics and preparing teachers to use e.g. dynamic statistical software tools (e.g. Lee and Hollebrands, 2008, 2011; Pfannkuch and Ben-Zvi, 2011; Pratt, Davies and Connor, 2011).

Moreover, the use of statistics in the current world grows in importance as the development in contemporary society is connected to the data boom. Teaching statistics should reflect this fact. Data and research method knowledge can help graduates not only in the labour market, but also to assess the socioeconomic situation, for example. Since media widely use numbers and statistics as arguments, basic knowledge of statistics and its application represents a necessary skill of a university educated person.

Statistics courses for humanities should be fully adjusted to students to be effective. A student should become the focal point in designing the course (Harris et al., 2007). The qualitative analysis shows that a large part of students finds statistics very distant in its logic. The way of introducing 
statistics to such students is of the highest importance. Statistics represents a discipline that can induce enthusiasm with correctly chosen methods, or at least show students the way to facilitate their work.

On the other hand, it can also completely dissuade students. Unfortunately, this is often the case due to poorly designed courses in a majority of statistical courses. Current trends in didactics implement various activation methods. However, such methods rarely penetrate statistics courses, according to students' statements. Students also point out that theoretical statistics comprises the prime aspect in their courses. Contrary to the described practice, Şahin, Ökmen and Kılıç (2020) highlight the advantages of student-centred methods and their positive impact on the students' results.

Students' sentiments towards statistics play an important role as well. Students do not trust statistics, which is connected to prejudice. University courses should eliminate such prejudice. Showing students the use of statistics in everyday life and their future career constitutes the main tool. Chew (2007) states that courses should employ good practice examples and proposes a model of creating examples with an adequate cognitive load. However, students complain in the survey about overly abstract theoretical classes and insufficient explanation of statistics fundamentals along with non-conceptual definition memorising. The presented research showed that women have a larger block in terms of statistics than men. They are similarly not comfortable with the combination of statistics and the English language used in various types of statistical software. In addition, these barriers, combined with a persistent gender gap in statistical reasoning (e.g. Martin, Hughes and Fugelsang, 2017), significantly disadvantage women in the study of statistics. The results further show that respondents with a completed statistics course tend to have a more positive approach to quantitative research methods. Two aspects can be causing this. Either the fact that one completes a statistics course improves one's attitude towards statistics and students are not afraid to use it in practice. Or natural sciences impact the results significantly. Statistics and quantitative methods are more taught in this branch and students with a more positive approach to statistics and mathematics enrol.

Chew (2007) further emphasises that the classroom atmosphere must enable and encourage elaborative processing and examples. Although Fajčíková and Fejfarová (2019) point out that evaluating teachers does not impact the course quality evaluation by university students, the qualitative research part of this paper shows that students who took a statistics course assess the given teacher's personality and approach to the course. Despite respecting the teacher's expertise, the students often miss a teacher's ability to explain statistics comprehensibly. Moreover, many students do not feel good in statistics classes and consider the statistics teacher's behaviour to be arrogant.

It is alarming that in the era when using digital technologies represents a daily occurrence almost one third of the respondents who completed statistical subjects during their university studies did not get familiar with any statistical software, not even with MS Excel. The importance of using statistical software is emphasized by numerous researchers involved in the teaching of statistics (e.g. Velleman and Moore, 1996; Pratt, Davies and Connor, 2011; Davidson et al., 2019). Their conclusions correspond to our findings, i.e. students who participated in a statistics course supported with using statistical software have less problems understanding statistics, using English in statistics and are more aligned with the supervisor's requirements for using statistical methods in their final thesis.

Moreover, Davidson et al. (2019) point to the development of statistical freeware such as JASP. The advantage of free software is undoubtedly that students can use them even after graduation because they do not need to buy a license. Some students pointed this out in the qualitative part of the research as well. However, the results show that the JASP and Jamovi freeware are the least known among Czech students and in lessons used only occasionally (3\% and $2 \%$, respectively). Both software brands offer a huge variety of statistical procedures that cover syllabi of basic statistics courses. Poláčková and Jindrová (2010) point out the use of statistical software with available instruction tutorials which can help the less experienced IT users, who usually have more troubles with navigation in a statistical programme. The opinions of some respondents are in line with the research as the respondents prefer statistical software with tutorials available online.

To use the software in lessons proves both practical and motivational. Students are usually afraid of calculations in statistics (Cobb, 1992), as confirmed by the presented results. When using software, the calculations are done by a computer and students can focus on input conditions of statistical methods and on the interpretation of results. Respondents mention that using the software can save a student a lot of time and facilitate work to ones who are not so strong in mathematics. This is more practical than being stressed by calculations.

Moreover, a student is more focused on using statistics in the given field and its practical significance (Hsu, Wang and Chiu, 2009). However, students complained about the problem of interpreting results in the qualitative part of the presented research. This illustrates the impossibility of teaching with software without a thorough course concept. Any teaching aid may be successful only if the teacher realises the advantages of its implementation and identifies with them (Fullan and Stiegelbauer, 1991). Therefore, teachers should be convinced of the advantages and suitability of the use of the given statistical software brand. The results above demonstrate that statistical software represents a tool for students to help overcome the initial fear of discipline and facilitate their work. These aspects represent a strong argument for including statistical software in classes and should be considered in statistical course preparation.

The cluster analysis grouped respondents into four clusters according to their responses to the sentiment questions about using statistics. Respondents in each cluster exhibit different potential. They express different needs in terms of statistics classes and the use of statistical software in the courses. Cluster 1 members may be characterised as undecided, 
cluster 2 respondents as eternal statistics adversaries, cluster 3 members as temporary statistics adversaries, and cluster 4 as statistics fans. The group of the undecided respondents includes respondents with a high probability to get convinced of the benefits of statistics. They feel no mental block against statistics and can admit the importance of the field. They are not completely convinced and adhere to neutral sentiment in their statements. Suitably built classes would draw statistics nearer to Cluster 1 members. As Hsu, Wang and Chiu (2009) described teaching about statistical software might play a significant role in the process. However, the cluster 2 of eternal statistics adversaries gives the impression that even completing a customised statistics course would not convince them of the advantages. They do not comprehend statistics, never needed it and never will. They probably see no benefit in statistics. Therefore, working with statistical software might represent a further burden and turn-off for them. Griffith et al. (2012) provided a similar description of people who view statistics negatively. The group considers the difficulty and complexity to be the largest issue of statistics. Besides, they described its non-use in future careers and stated that they dislike mathematics as well (Griffith et al., 2012).

The so-called temporary statistics adversaries in Cluster 3 do not incline towards statistics and will never pursue it on their own. As they may have come across statistics due to their thesis supervisors' requirements, they may even admit the importance of statistics. A suitably prepared statistics course would help the group to get rid of the mental block against the field. Since they state that they do not wish to understand statistics, working with statistical software might provide an opening for using statistics. The fact that the software does a lot of the work for them might convince them. They do not need to deal with the "tyranny of the computable" as Cobb (2007) describes the need to understand necessary calculations. This group might also be persuaded by real-life data use in classes. Gould (2010) claims that a modern statistics course must adjust to the fact that students' first exposure to data occurs outside academia - in the newspaper, on the internet etc. The classes should use students' knowledge of some diagrams and basic statistical terms and use their own experience as a starting point, describing the statistics surrounding us and showing them its practical use. Holmes (2003) supports this idea by stating that statistics classes should consider a student's real-life and world perception.

Cluster 4 includes so-called statistics fans, i.e. people who have some command of statistics and understand its importance. This group shows the potential to develop their statistical literacy, e.g. by using statistical software in classes. This might broaden their knowledge and skills through new statistical tests and better assessment of the use of individual tests.

Considering the curriculum, its range and conception of a potential statistics course prove relevant for all clusters. Each group exhibits different needs. Group 2 (eternal adversaries) will probably perceive even the introduction to statistical methods as a necessary evil. The content of the course will be crucial for the other three groups, however. Ideally, completing such a course should overlap into initial research phases, i.e. the research design, compiling the research tool, selecting suitable methods etc. (Justice, Zieffler and Garfield, 2017; Holmes, 2003). Deciding on the statistical software, working with it and assessing its use potential plays an essential role in all these groups, although the role differs in each group (see above).

The main limitation of this research is a wide range of study fields of respondents, as was stated in part of Methodology and research questions. However, this research serves mainly as the first probe to point out the problem. The authors also plan to do a more detailed examination on a smaller sample of respondents.

\section{CONCLUSION}

The paper's main aim is to determine the approach to teaching statistics at universities and to give an overview of the mainly used didactic materials and teaching methods. To understand the results thoroughly, students were asked to comment freely on the statistics courses and the used statistical software.

Although current teaching practice works with an array of activation methods, the survey results indicate that these methods have not penetrated statistics courses at Czech universities. The design of statistics courses remains rigid and does not reflect current needs of students. Theoretical presentation of definitions prevails over specific examples and practical verification of statistical methods. Thus, students have virtually no opportunity to master individual statistical operations. In the context of such inconsistent statistics teaching practice, any attempt to bring the discipline nearer to students and facilitate their work is desired. Using statistical software in classes, ideally, such software that remains available to students after completing the course represents a possible solution.

The results can be an impulse for improvement not only of teaching statistics but also of teachers' approach towards students. The importance of quantitative research increases as well as the importance of the question of how to teach the current generation necessary statistical thinking. Traditional teaching methods are not effective enough in the present dynamic world and teaching requires modernisation and an innovative approach. The results show that these changes cannot be done without statistical software and teachers open to changes. In the future, the authors plan a more detailed analysis, which will offer specific solutions for various fields of study regarding the cognitive load theory.

\section{ACKNOWLEDGEMENT}

This work has been supported by Charles University Research Centre No. UNCE/HUM/024. 
Aberson, C. L., Berger, D. E., Healy, M. R. and Romero, V. L. (2002) 'An Interactive Tutorial for Teaching Statistical Power', Journal of Statistics Education, Vol. 10, No. 3. https://doi.org/10.1080/10 691898.2002.11910682

Billig, S. H. and Waterman, A. S. (ed.) (2014) Studying servicelearning: Innovations in education research methodology, New York, NY: Routledge.

Chew, S. L. (2007) 'Designing effective examples and problems for teaching statistics', in Dunn, D. S., Smith, R. A. and Beins, B. (ed.) Best practices for teaching statistics and research methods in the behavioral sciences, pp. 73-91, Mahwah, NJ: Erlbaum.

Cobb, G. (1992) 'Teaching statistics', in Steen L. A. (ed.) Heeding the call for change: Suggestions for curricular action, Vol. 22, pp. 3-43, Washington, DC: Mathematical Association of America.

Cobb, G. W. (2007) 'The introductory statistics course: A Ptolemaic curriculum?', Technology innovations in statistics education, Vol. 1, No. 1. https://doi.org/10.5070/T511000028

Curtin, R., Presser, S., and Singer, E. (2000) 'The effects of response rate changes on the index of consumer sentiment', Public Opinion Quarterly, Vol. 64, No. 4, pp. 413-428. https://doi. org/10.1086/318638

Davidson, H., Jabbari, Y., Patton, H., O’Hagan, F., Peters, K., and Cribbie, R. (2019) 'Statistical Software Use in Canadian University Courses: Current Trends and Future Directions', Teaching of Psychology, Vol. 46, No. 3, pp. 246250. https://doi.org/10.1177/0098628319853940

De Leeuw, E. D. and Hox, J. J. (2008) 'Self-administered questionnaires: mail surveys and other applications', in De Leeuw, E. D., Hox, J. J. and Dillman, D. (ed.) International handbook of survey methodology, pp. 239-263, New York, NY: Routledge. https://doi.org/10.4324/9780203843123

Dempster, M. and McCorry, N. K. (2009) 'The Role of Previous Experience and Attitudes Toward Statistics in Statistics Assessment Outcomes among Undergraduate Psychology Students', Journal of Statistics Education, Vol. 17, No. 2. https:// doi.org/10.1080/10691898.2009.11889515

Erlingsson, Ch. and Rysiewicz, P. (2017) 'A hands-on guide to doing content analysis', African Journal of Emergency Medicine, Vol. 7, No. 3, pp. 93-99. https://doi.org/10.1016/j.afjem.2017.08.001

Fajčíková, A. and Fejfarová, M. (2019) 'Evaluation of the Quality of Teaching from the Perspective of University Students', Journal on Efficiency and Responsibility in Education and Science, Vol. 12, No. 2, pp. 34-40. https://doi.org/10.7160/eriesj.2019.120201

Fullan, M. G. and Stiegelbauer, S. (1991) The New Meaning of Educational Change, New York: Teachers College Press.

Gould, R. (2010) 'Statistics and the modern student', International Statistical Review, Vol. 78, No. 2, pp. 297-315. http://dx.doi. org/10.1111/j.1751-5823.2010.00117.x

Griffith, J. D., Adams, L. T., Gu, L. L., Hart, C. L. and NicholsWhitehead, P. (2012) 'Students' attitudes toward statistics across the disciplines: a mixed-methods approach', Statistics Education Research Journal, Vol. 11, No. 2, pp. 45-56. https:// doi.org/10.52041/serj.v11i2.328

Harris, C. M., Mazoué, J. G., Hamdan, H., and Casiple, A. R. (2007) 'Designing an online introductory statistics course', in Dunn, D. S., Smith, R. A. and Beins, B. (ed.) Best practices for teaching statistics and research methods in the behavioral sciences, pp. 93-108. Mahwah, NJ: Erlbaum.
Hendl, J. (2005) Kvalitativni výzkum: základni metody a aplikace [Qualitative Research. Basic Methods and Applications], Prague: Portál.

Hindls, R., and Hronová, S. (2005) 'Jak výuka odrazuje nestatistiky od statistiky' [How teaching discourages non-statisticians from statistics], Statistika, Vol. 42, No. 2, pp. 168-172.

Holmes, P. (2003) '50 Years of Statistics Teaching in English Schools: Some Milestones', Journal of the Royal Statistical Society: Series D (The Statistician), Vol. 52, No. 4, pp. 439-463. https:// doi.org/10.1046/j.1467-9884.2003.372 1.x

Hsu, M. K., Wang, S. W. and Chiu, K. K. (2009) 'Computer attitude, statistics anxiety and self-efficacy on statistical software adoption behavior: An empirical study of online MBA learners', Computers in Human Behavior, Vol. 25, No. 2, pp. 412-420. https://doi. org/10.1016/j.chb.2008.10.003

Huynh, M. and Baglin, J. (2017) 'Teaching statistics through data investigations in Australian secondary schools: An island-based pilot project', International Journal of Innovation in Science and Mathematics Education, Vol. 25, No. 1, pp. 49-63.

Hybšová, A. (2017) Statistická gramotnost studentů učitelstvi prírodopisu/biologie v České republice [Biology pre-service teacher's statistical literacy in the Czech republic], [PhD thesis], Prague: PedF UK.

Justice, N., Zieffler, A., and Garfield, J. (2017) 'Statistics Graduate Teaching Assistants'beliefs, Practices And Preparation For Teaching Introductory Statistics', Statistics Education Research Journal, Vol. 16, No. 1, pp. 294-319.

Kurniawan, D. A., Astalini, A., Darmaji, D., and Melsayanti, R. (2019) 'Students' Attitude towards Natural Sciences', International Journal of Evaluation and Research in Education, Vol. 8, No. 3, pp. 455-460. http://doi.org/10.11591/ijere.v8i3.16395

Law, K. M. Y., Lee, V. C. S. and Yu, Y. T. (2010) 'Learning motivation in e-learning facilitated computer programming courses', Computers \& Education, Vol. 55, No. 1, pp. 218-228. https://doi. org/10.1016/j.compedu.2010.01.007

Lee, R. and Fielding, N. (2004) 'Tools for Qualitative Data Analysis', in Hardy, M. and Bryman, A. (ed.) Handbook of Data Analysis, London: Sage, pp. 529-546. https://dx.doi. org/10.4135/9781848608184.n23

Lee, H. S. and Hollebrands, K. (2008) 'Preparing to teach mathematics with technology: An integrated approach to developing technological pedagogical content knowledge', Contemporary Issues in Technology and Teacher Education, Vol. 8, No. 4., pp. 326-341.

Lee, H. S. and Hollebrands, K. F. (2011) 'Characterizing and developing teachers' knowledge for teaching statistics', in Batanero, C., Burrill, G. and Reading, Ch. (ed.) Teaching statistics in school mathematics-Challenges for teaching and teacher education: A joint ICMI/IASE study, Dordrecht: Springer, pp. 359-369. https://doi.org/10.1007/978-94-007-1131-0

Martin, N., Hughes, J. and Fugelsang, J. (2017) 'The roles of experience, gender, and individual differences in statistical reasoning', Statistics Education Research Journal, Vol. 16, No. 2, pp. 454-475.

Mazouchová, A., Jedličková, T. and Hlaváčová, L. (2020) 'Using statistical software at Czech universities', Proceedings of the 17th International Conference Efficiency and Responsibility in Education (ERIE 2020). Prague, pp.181-188. 
Moore, D. L., and Tarnai, J. (2002) 'Evaluating nonresponse error in mail surveys', in Groves, R. M., Dillman, D. A., Eltinge, J. L., and Little, R. J. A. (ed.) Survey Nonresponse, New York, NY: John Wiley \& Sons, pp. 197-211.

Mustafa, R. Y. (1996) 'The challenge of teaching statistics to nonspecialists', Journal of statistics education, Vol. 4, No. 1. https:// doi.org/10.1080/10691898.1996.11910504

Pfannkuch, M. and Ben-Zvi, D. (2011) 'Developing teachers' statistical thinking', in Batanero, C., Burrill, G. and Reading, Ch. (ed.) Teaching statistics in school mathematics-Challenges for teaching and teacher education: A joint ICMI/IASE study, Dordrecht: Springer, pp. 323-333. http://dx.doi.org/10.1007/97894-007-1131-0_31

Poláčková, J. and Jindrová, A. (2010) 'Innovative Approach to Education and Teaching of Statistics', Journal on Efficiency and Responsibility in Education and Science, Vol. 3, No. 1, pp. 14-27.

Pratt, D., Davies, N., and Connor, D. (2011) 'The role of technology in teaching and learning statistics', in Batanero, C., Burrill, G. and Reading, Ch. (ed.) Teaching statistics in school mathematicsChallenges for teaching and teacher education: A joint ICMI/ IASE study, Dordrecht: Springer, pp. 97-107. http://dx.doi. org/10.1007/978-94-007-1131-0 13

Ralston, K., MacInnes, J., Crow, G., and Gayle, V. J. (2016) We need to talk about statistical anxiety: A review of the evidence around statistical anxiety in the context of quantitative methods pedagogy, London: NCRM.

Şahin Ş., Ökmen B. and Kılıç A. (2020) 'Effects of Teaching the Learning Psychology Course in Different Ways on the Student's Success and Attitudes', Journal on Efficiency and Responsibility in Education and Science, Vol. 13, No. 3, pp. 113-129. http:// dx.doi.org/10.7160/eriesj.2020.130302
Singer, E., van Hoewyk, J., \& Maher, M. P. (2000) 'Experiments with incentives in telephone surveys', Public Opinion Quarterly, Vol. 64, No. 2, pp. 171-188. http://dx.doi.org/10.1086/317761

Skalská, H. (2019) 'Výuka statistiky pro informatiku a management $v$ éře datové vědy' [Statistics education for informatics and management in the era of data science], Informačni bulletin České statistické společnosti. Vol. 30, No. 4, pp. 1-9.

Steinberger, P. (2020) 'Assessing the Statistical Anxiety Rating Scale as applied to prospective teachers in an Israeli Teacher-Training College', Studies in Educational -Evaluation, Vol. 64, 100829. https://doi.org/10.1016/j.stueduc.2019.100829

Stejskalová I., Komárková L., Bednářová M. and Štrach P. (2019) 'Student Adoption of a Non-Traditional Teaching Method in Accounting: How Previous Experience Impedes Willingness to Change', Journal on Efficiency and Responsibility in Education and Science, Vol. 12, No. 1, pp. 1-11. http://dx.doi.org/10.7160/ eriesj.2019.120101

Strauss, A. L. and Corbin, J. (1999) Základy kvalitativního výzkumu: postupy a techniky metody zakotvené teorie [Basics of Qualitative Research. Techniques a Procedures for Developing Grounded Theory], Brno: Sdružení Podané ruce.

Švarríček, R. and Šed'ová, K. (2007) Kvalitativni výzkum v pedagogických védách [Qualitative research in pedagogical sciences], Prague: Portál.

Velleman, P. F., and Moore, D. S. (1996) 'Multimedia for teaching statistics: Promises and pitfalls', The American Statistician, Vol. 50, No. 3, pp. 217-225. https://doi.org/10.2307/2684658

Widenská, E. (2014) 'Efficiency of Practicing with Materials Using ICT and Paper Ones in Mathematics', Journal on Efficiency and Responsibility in Education and Science, Vol. 7, No. 2, pp. 3743. https://doi.org/10.7160/eriesj.2014.070203 